\title{
A new way to test the physical properties of spider
} silk

\section{Yue Zhao}

Yanrong Li

Khuat Thi

Thu Hien

Goro Mizutani

Harvey N. Rutt

\section{Video Byte}

Keywords: spider silk, silk protein, gene expression is straightforward, second harmonic generation microscopy, fiber, stretching, Surface and Interface Analysis, materials science

Posted Date: September 20th, 2019

DOl: https://doi.org/10.21203/rs.2.15162/v1

License: (c) (1) This work is licensed under a Creative Commons Attribution 4.0 International License. Read Full License 


\section{Abstract}

Stronger than steel yet more flexible than nylon, spider silk is one of the most impressive materials in the natural world Many researchers have tried to manufacture artificial spider silk Producing silk protein through gene expression is straightforward, but getting the subsequent spinning process to perform like the real thing has been challenging A new study describes a quick and simple way to monitor the properties of natural and artificial spider silk using second harmonic generation microscopy Researchers used the method to track the protein structure of spider silk as it stretched Stretching caused the $\beta$-sheets in the silk proteins to align in one direction and was sensitively detected by second harmonic generation When stretched too far, the silk separated into several thin fibers The structure of these fibers changed during stretching, making each fiber stronger and lengthening the time before they broke Beyond giving new insights into the physical properties of the silk, the work validates an effective way to test the material which could aid the quest to manufacture high-performing spider silk Zhao, et al. Observation of spider silk by femtosecond pulse laser second harmonic generation microscopy. (2018) Surface and Interface Analysis 